\title{
ANALISIS SEKTOR POTENSIAL DI KABUPATEN KLUNGKUNG
}

\author{
I Nengah Jaya Widiantara ${ }^{1}$ \\ Made Kembar Sri Budhi ${ }^{2}$
${ }^{1,2}$ Program Studi Ekonomi Pembangunan Fakultas Ekonomi dan Bisnis Unversitas
Udayana (Unud), Bali, Indonesia
e-mail: jayawidiantara14@gmail.com

\begin{abstract}
Analysis of Potential Sectors in Klungkung Regency. Klungkung Regency as one of the regions in Bali Province has a considerable opportunity in developing the potential of the region it has in order to support the economic development of Klungkung Regency. This study aims to analyze the potential sectors in Klungkung Regency in terms of Gross Regional Domestic Product. The data used secondary data. This study used GRDP data from the period 20122016. The analysis technique used are Location Quotients (LQ) analysis, Growth Ratio Model (MRP) and Overlay. The results show that the potential sectors in Klungkung Regency during the 2012-2016 period are 4 sectors, namely (1) manufacturing industry sector ; (2) information and communication; (3) health services and social activities; and (4) other services. The results of the analysis which show that for these four sectors have a positive growth rate and make a large contribution in the GRDP of Klungkung Regency. The government should make several policies to improve the performance of these sectors by providing stimuli. in the form of capital. With the existence of capital, in this case such as credit loans and subsidies so that later sectors that have not this potential can develop into a potential sector.
\end{abstract}

Keywords: economic growth, potential sector

\begin{abstract}
Abstrak: Analisis Sektor Potensial di Kabupaten Klungkung. Kabupaten Klungkung sebagai salah satu daerah di Provinsi Bali memiliki peluang yang cukup besar dalam mengembangkan potensi daerah yang dimiliki dalam rangka mendukung pembangunan ekonomi Kabupaten Klungkung. Penelitian ini bertujuan untuk untuk menganalisis sektor potensial di Kabupaten Klungkung dilihat dari sisi Produk Domestik Regional Bruto (PDRB). Data yang dipergunakan dalam penelitian ini adalah data sekunder yang diperoleh dari BPS. Penelitian ini menggunakan data PDRB dari periode tahun 2012-2016. Teknik analisis yang digunakan dalam penelitian ini adalah analisis Location Quotients (LQ), Model Rasio Pertumbuhan (MRP) dan Overlay. Hasil analsisis menunjukkan bahwa sektor yang potensial di Kabupaten Klungkung selama periode tahun 2012-2016 terdapat 4 sektor yaitu (1) sektor industri pengolahan; (2) informasi dan komunikasi; (3) jasa kesehatan dan kegiatan sosial; dan (4) jasa lainnya. Hal ini dilihat dari hasil analisis yang menujukkan bahwa untuk keempat sektor ini memiliki tingkat pertumbuhan yang positif dan memberikan kontribusi yang besar dalam PDRB Kabupaten Klungkung. Merujuk kepada hasil penelitian maka pemerintah sebaiknya membuat beberapa kebijakan untuk meningkatkan kinerja dari sektor-sektor tersebut dengan cara memberikan rangsangan dalam bentuk modal. Dengan adanya modal, dalam hal ini seperti pinjaman kredit maupun subsidi sehingga nantinya sektor-sektor yang belum potensial ini dapat berkembang menjadi sektor yang potensial.
\end{abstract}

Kata kunci: pertumbuhan ekonomi, sektor potensial 


\section{PENDAHULUAN}

Pembangunan ekonomi Indonesia pada dasarnya mempunyai empat dimensi pokok antara lain, (1) pertumbuhan, (2) penanggulangan kemisikan, (3) keberlanjutan pembangunan dari masyarakat agraris menjadi masyarakat industri, dan (4) perubahan atau transformasi ekonomi. Kegiatan ekonomi menjadi salah satu indikator penting keberhasilan pembangunan baik lingkup nasional, provinsi, kabupaten ataupun kota (Dayuh Rimbawan, 2010). Pembangunan mempunyai tujuan untuk meningkatkan kesejahteraan masyarakat baik dilihat dari aspek ekonomi ataupun sosial. Adanya perbedaan pertumbuhan ekonomi antar daerah akan menimbulkan ketimpangan distribusi pendapatan (Adipuryanti dan Sudibia, 2015).

Dalam mempercepat proses pembangunan daerah suatu daerah selayaknya mengandalkan sektor-sektor yang padat modal yang memberikan kontribusi lebih tinggi dalam pembagunan daerah (Ridhwan, 2013). Menurut Seran (2017), salah satu prasayarat dalam upaya peningkatan pembangunan disuatu daerah adalah dengan melakukan transformasi structural ekonomi. Transformasi struktural merupakan prasyarat dari peningkatan dan kesinambungan pertumbuhan dan penanggulangan kemiskinan serta sebagai sentra pendukung untuk keberlanjutan pembangunan itu sendiri (Margareni dkk., 2016). Wiwekananda (2016) menyebutkan bahwa tingkat perubahan struktural dan sektoral yang tinggi, berkaitan dengan proses pertumbuhan ekonomi. Sektor ekonomi tidak hanya berpengruh terhadap Produk Domestik Bruto (PDB) atau Produk Domestik Regional Bruto (PDRB) dan tingkat penyerapan kerja, tetapi juga berperan penting terhadap laju pertumbuhan ekonomi (Suharyadi dkk., 2012).

Indonesia yang saat ini menjalankan kebijakan otonomi daerahnya, pemerintah senantiasa memperhatikan laju pertumbuhan ekonomi Indonesia setiap tahunnya. Kebijakan otonomi daerah yang dijalankan Indonesia saat ini memberikan kesempatan besar bagi seluruh pemerintah provinsi dan pemerintah kabupaten/kota di Indonesia untuk mengatur daerahnya sendiri sesuai dengan peraturan perundang-undangan (Miranti, 2014). Namun, dalam menjalankan otonomi daerah tersebut, hal utama yang menjadi tantangan terbesar bagi pemerintah daerah adalah mengidentifikasi dan pemahaman terhadap potensi yang dimiliki oleh daerah yang diembannya (Anissa, 2013). Daerah yang telah mengetahui dengan benar potensi yang dimiliki daerahnya, maka akan dapat memanfaatkan potensi tersebut demi keberlangsungan perekonomian daerahnya. Berbeda halnya dengan daerah yang tidak mengetahui dengan benar potensi yang dimiliki, maka pemerintah daerah tidak dapat secara optimal dalam memanfaatkan yang menjadi potensi di daerahnya.

Pertumbuhan ekonomi adalah suatu peluang, karena ekonomi yang tumbuh akan tercipta banyak peluang (Hukom, 2015). Agar pertumbuhan ekonomi terus berlangsung, diharapkan terjadi perubahan atau transformasi struktur ekonomi. Pertumbuhan ekonomi suatu daerah tidak tumbuh secara bersamaan (Artana Yasa, 2015). Tetapi akan butuh waktu yang berbeda untuk berkembang di setiap daerahnya. Jika pertumbuhan terjadi di satu daerah. daerah di sekitarnya akan mulai mengikuti pertumbuhan tersebut. Skala nasional, peningkatan pendapatan dicerminkan pada Produk Nasional Bruto (PNB), sedangkan daerah dengan Produk Domestik Regional Bruto (PDRB) (Sri Budhi, 2013).

Pertumbuhan ekonomi dapat ditunjukkan dari besarnya pendapatan Produk Domestik Regional Bruto (Afzal, 2007). PDRB tersebut diperoleh melalui pendapatan total setiap orang yang ada di dalam perekonomian, kenaikan produk dan jasa setiap tahunnya juga disebut pertumbuhan ekonomi (Altiner, 2012). Penggunaaan sumber daya yang efisien juga sangat diperlukan (Woods, 2007). Provinsi Bali merupakan provinsi di Indonesia yang juga sangat memperhatikan laju pertumbuhan ekonominya. Tabel 1 menujukkan pertumbuhan ekonomi menurut Kabupaten/Kota di Provinsi Bali. 
Tabel 1. Pertumbuhan Ekonomi Menurut Kabupaten/Kota di Provinsi Bali (dalam \%)

\begin{tabular}{llllllc}
\hline Kabupaten/Kota & $\mathbf{2 0 1 2}$ & $\mathbf{2 0 1 3}$ & $\mathbf{2 0 1 4}$ & $\mathbf{2 0 1 5}$ & $\mathbf{2 0 1 6}$ & Rata-Rata \\
\hline Jembrana & 5,89 & 6,11 & 5,69 & 6,05 & 6,23 & 5,95 \\
Tabanan & 6,11 & 6,12 & 6,45 & 6,53 & 6,24 & 6,12 \\
Badung & 7,07 & 7,64 & 6,82 & 6,98 & 6,27 & 6,79 \\
Gianyar & 7,15 & 7,08 & 6,82 & 6,79 & 6,34 & 6,30 \\
Klungkung & 6,11 & 6,25 & 6,05 & 5,98 & 6,10 & 6,26 \\
Bangli & 6,14 & 6,2 & 5,94 & 5,82 & 6,21 & 6,23 \\
Karangasem & 5,43 & 5,93 & 6,16 & 6,01 & 6,00 & 5,92 \\
Buleleng & 6,44 & 6,78 & 7,15 & 6,96 & 6,11 & 6,01 \\
Kota Denpasar & 7,16 & 7,51 & 6,96 & 7,00 & 6,18 & 6,50 \\
BALI & 6,66 & 6,96 & 6,69 & 6,73 & 6,04 & 6,24 \\
\hline
\end{tabular}

Sumber : Badan Pusat Statistik Provinsi Bali, 2017

Dilihat di Tabel 1 bahwa rata-rata pertumbuhan ekonomi di kabupaten/kota Provinsi Bali tahun 2012-2016 yang tertinggi yaitu Kabupaten Badung dengan rata-rata pertumbuhan ekonomi sebesar 6,79 persen, pertumbuhan ekonomi terbesar kedua pada Kota Denpasar sebesar 6,50 persen. Kabupaten Gianyar memiliki pertumbuhan ekonomi terbesar ketiga dengan pertumbuhan ekonomi sebesar 6,30 persen dan 6,75 persen. Berbeda dengan 6 (enam) kabupaten lainnya yaitu Kabupaten Buleleng, Kabupaten Tabanan, Kabupaten Klungkung, Kabupaten Bangli, Kabupaten Karangasem dan Kabupaten Jembrana memiliki pertumbuhan ekonomi yang berada di bawah rata-rata pertumbuhan ekonomi Provinsi Bali. Melihat hal ini maka Kabupaten Klungkung dengan rata-rata pertumbuhan ekonomi sebesar 6,26 persen perlu diteliti terkait dengan sektor-sektor potensial yang harus dikembangkan agar laju pertumbuhan ekonomi di Kabupaten Klungkung semakin meningkat.

Perkembangan kontribusi sektoral terhadap PDRB menurut Kabupaten/Kota di Provinsi Bali secara rinci dijelaskan pada Tabel 2.

Berdasarkan Tabel 2 menujukkan kabupaten dengan kontribusi yang paling tinggi adalah Kabupaten Badung sebesar 29.178,33 juta rupiah, sedangkan kontribusi PDRB paling rendah adalah Kabupaten
Bangli sebesar 3688,00 juta rupiah, kemudian terendah kedua adalah Kabupaten Klungkung sebesar 4813,03 juta rupiah. Melihat hal ini maka Kabupaten Klungkung perlu diteliti terkait dengan sektor-sektor potensial yang harus dikembangkan agar laju pertumbuhan ekonomi di Kabupaten Klungkung semakin meningkat.

Pembangunan sektor-sektor ekonomi dengan menganalisis potensi ekonomi Kabupaten Klungkung sangat diperlukan yakni dengan mengetahui terlebih dahulu sektor potensial untuk meningkatkan perekonomian wilayah. Kemungkinan terjadinya pergeseran pangsa sektor-sektor ekonomi Kabupaten Klungkung juga harus mendapatkan perhatian lebih dari pemerintah Kabupaten Klungkung. Hal tersebut penting dilakukan dijadikan sebagai dasar dalam perencanaan pembangunan ekonomi di Kabupaten Klungkung.

Perubahan pergeseran penyerapan tenaga kerja dan kontribusi sektoral terhadap PDRB menyebabkan struktur perekonomian mengalami perubahan dari struktur perekonomian tradisional yang mengandalkan sektor pertanian menuju struktur perekonomian modern dengan lebih mengandalkan sektor industri, perdagangan dan jasa (Sinaga, 2015). Perkembangan perekonomian global mendorong setiap daerah untuk mempercepat proses pembangunan 
Tabel 2. Konstribusi Sektoral Terhadap PDRB Menurut Kabupaten/Kota di Provinsi Bali Tahun 2016 (dalam juta rupiah)

\begin{tabular}{|c|c|c|c|c|c|c|c|c|c|}
\hline \multirow{2}{*}{$\begin{array}{c}\text { Lapangan Usaha/ } \\
\text { Sektor }\end{array}$} & \multicolumn{9}{|c|}{ Kabupaten/Kota } \\
\hline & Jembrana & Tabanan & Badung & Gianyar & Klungkung & Bangli & Karangasem & Bulelelng & Denpasar \\
\hline Pertanian & 1527,57 & 2726,58 & 2182,15 & 1950,00 & 1105,60 & 939,39 & 2392,04 & 4047,03 & 1976,25 \\
\hline $\begin{array}{l}\text { Pertambangan \& } \\
\text { Penggalian }\end{array}$ & 70,70 & 156,34 & 102,08 & 256,99 & 207,21 & 86,62 & 338,77 & 226,10 & 19,01 \\
\hline Industri Pengolahan & 382,78 & 771,13 & 1387,24 & 1928,59 & 443,36 & 372,71 & 381,59 & 1124,68 & 2015,85 \\
\hline $\begin{array}{l}\text { Listrik, Gas \& Air } \\
\text { Bersih }\end{array}$ & 17,57 & 37,03 & 146,51 & 38,84 & 16,71 & 3,58 & 21,69 & 53,66 & 215,36 \\
\hline Konstruksi & 743,63 & 1255,52 & 2817,43 & 1732,06 & 409,68 & 277,09 & 535,83 & 1595,87 & 2718,74 \\
\hline $\begin{array}{l}\text { Perdag., Hotel \& } \\
\text { Restoran }\end{array}$ & 1714,12 & 3815,99 & 9878,48 & 4295,86 & 877,63 & 800,46 & 1271,53 & 5081,45 & 9321,18 \\
\hline $\begin{array}{l}\text { Pengangkutan \& } \\
\text { Komunikasi }\end{array}$ & 2890,38 & 1072,43 & 7370,03 & 1299,97 & 648,59 & 232,22 & 1739,98 & 1465,27 & 2416,20 \\
\hline $\begin{array}{l}\text { Keu. Real Estat, \& } \\
\text { Jasa Perusahaan }\end{array}$ & 677,96 & 1213,01 & 2092,93 & 1421,14 & 326,33 & 228,90 & 467,34 & 1850,05 & 3234,21 \\
\hline Jasa-Jasa & 716,94 & 2001,30 & 3201,48 & 2249,95 & 777,90 & 747,02 & 1483,5 & 3381,73 & 6516,99 \\
\hline PDRB & $7.579,12$ & $12.651,40$ & $29.178,33$ & $15.173,31$ & $4.813,03$ & $3.688,00$ & $8.992,28$ & $18.824,84$ & $28.433,25$ \\
\hline
\end{tabular}

Sumber : Badan Pusat Statistik Provinsi Bali, 2017

daerah. Upaya untuk mencapai tujuan dari pembangunan ekonomi daerah memerlukan peran sinergis dari pemerintah daerah dan masyarakat yang saling bekerjasama dan meningkatkan komitmennya sehingga proses pembangunan daerah bisa berlangsung secara berkelanjutan (Suahasil, 2003). Hal ini menyebabkan pemerintah daerah perlu menjalin kerjasama dengan masyarakat atau sektor swasta dengan menggunakan sumber daya yang diperlukan untuk merancang dan merangsang perkembangan kegiatan ekonomi daerah (Arsyad, 1999:108).

Ukuran-ukuran mengenai keterkaitan ekonomi pada dasarnya menggambarkan hubungan antara perekonomian daerah dengan lingkungan sekitarnya. Analisis $L Q$ merupakan teknik yang sangat berguna dalam menganalisis perubahan stuktur ekonomi daerah dibanding perekonomian nasional. Analisis ini memberikan data tentang kinerja perekonomian dalam 3 bidang yang berhubungan satu sama lain yaitu pertumbuhan ekonomi daerah diukur dengan cara menganalisis perubahan pengerjaan agregat secara sektoral dibandingkan dengan perubahan sektor yang sama diperekonomian yang dijadikan acuan.

Pergeseran diferensial membantu kita dalam menentukan seberapa jauh daya saing industri daerah (lokal) dengan perekonomian yang dijadikan acuan. Oleh karena itu, jika pergeseran diferensial dari suatu industriadalah positif, maka industri tersebut lebih tinggi daya saingnya ketimbang industri yang sama pada perekonomian yang dijadikan acuan. Pergeseran proposional mengukur perubahan relatif, pertumbuhan atau penurunan, pada daerah dibandingkan dengan perekonomian yang lebih besar dijadikan acuan. Pengukuran ini memungkinkan kita untuk mengetahui apakah perekonomian daerah terkonsentrasi pada industri-industri lebih cepat ketimbang perekonomian yang dijadikan acuan (Arsyad, 2004).

Peran sinergis antara pemerintah daerah dengan pemerintah pusat telah banyak dilakukan, mulai dari koordinasi, pengambilan keputusan dan lain sebagianya. Salah satu kebijakan yang dibuat pemerintah pusat adalah kebijakan khusus untuk daerah dalam rangka pembangunan daerah yaitu desentralisasi yang merupakan kapasitas daerah untuk menyesuaikan strategi pembangunan yang spesifik untuk memenuhi kebutuhan khusus daerah (Andrea et al., 2012). Berbagai kebijakan telah diambil oleh pemerintah untuk mendorong daerah-daerah 
Tabel 3 Produk Domestik Regional Bruto (PDRB) Kabupaten Klungkung Menurut Kategori Atas Dasar Harga KonstanTahun 2012-2016 (Juta Rupiah)

\begin{tabular}{|c|c|c|c|c|c|}
\hline Kategori PDRB & 2012 & 2013 & 2014 & 2015 & 2016 \\
\hline $\begin{array}{l}\text { Pertanian, Kehutanan, dan } \\
\text { Perikanan }\end{array}$ & 980450.38 & 999438.39 & 1047821.61 & 1105603.06 & 1115312.72 \\
\hline Pertambangan dan Penggalian & 211047.07 & 226261.27 & 224078.78 & 207208.30 & 197487.47 \\
\hline Industri Pengolahan & 352216.63 & 382739.26 & 415799.28 & 443364.18 & 476103.11 \\
\hline Pengadaan Listrik dan Gas & 4777.68 & 5159.47 & 5346.52 & 5629.75 & 5820.04 \\
\hline $\begin{array}{l}\text { Pengadaan Air, Pengelolaan } \\
\text { Sampah, Limbah dan Daur Ulang }\end{array}$ & 10129.83 & 10673.75 & 11365.58 & 11384.86 & 11854.10 \\
\hline Konstruksi & 361235.40 & 382164.25 & 385984.51 & 409683.96 & 470976.76 \\
\hline $\begin{array}{l}\text { Perdagangan Besar dan Eceran; } \\
\text { Reparasi Mobil dan Sepeda Motor }\end{array}$ & 313570.23 & 341398 & 363574.12 & 387498.13 & 414902.58 \\
\hline Transportasi dan Pergudangan & 113639.70 & 121745.53 & 132938.49 & 140154.80 & 147825.01 \\
\hline $\begin{array}{l}\text { Penyediaan Akomodasi dan } \\
\text { Makan Minum }\end{array}$ & 406333.63 & 440901.49 & 463968.06 & 490125.34 & 540024.07 \\
\hline Informasi dan Komunikasi & 423816.87 & 447520.68 & 475792.98 & 508440.38 & 551778 \\
\hline Jasa Keuangan dan Asuransi & 144122.53 & 163351.32 & 177817.09 & 193782.33 & 209541.74 \\
\hline Real Estate & 108000.43 & 115327.24 & 124709.66 & 132545.39 & 138719.93 \\
\hline Jasa Perusahaan & 39751.22 & 43344.24 & 46307.11 & 49617.47 & 51198.34 \\
\hline $\begin{array}{l}\text { Administrasi Pemerintahan, } \\
\text { Pertahanan dan Jaminan Sosial } \\
\text { Wajib }\end{array}$ & 245847.51 & 245227.36 & 269928.09 & 295998.94 & 315598.83 \\
\hline Jasa Pendidikan & 83401.63 & 94723.77 & 104144.22 & 116124.59 & 125737.04 \\
\hline $\begin{array}{l}\text { Jasa Kesehatan dan Kegiatan } \\
\text { Sosial }\end{array}$ & 150593.25 & 169581.45 & 189470.48 & 211511.41 & 229386.98 \\
\hline Jasa Lainnya & 87422.25 & 90895.34 & 97298.57 & 104653.36 & 112432.56 \\
\hline PDRB & 4036356.25 & 4280452.84 & 4536345.15 & 4813326.23 & 5114699.30 \\
\hline
\end{tabular}

Sumber : Badan Pusat Statistik Provinsi Bali, 2017

agar tidak bergantung lagi pada dana anggaran pusat dan harus mampu mendorong kontribusi sektor-ektor ekonomi lokalnya dalam upaya meningkatkan Pendapatan Asli Daerah (PAD), sehingga dapat mendukung untuk suksesnya pelaksanaan pembangunan daerah tersebut (Al-Habees, 2012).

Pembangunan daerah ini bukanlah hanya masalah jangka pendek, tetapi adalah masalah kompleks yang berkelanjutan dan memerlukan waktu jangka panjang. Tolak ukur yang dapat digunakan dalam menilai keberhasilan suatu daerah dalam pembangunan adalah pertumbuhan ekonomi daerah. Pertumbuhan ekonomi merupakan proses kenaikan output perkapita yang terjadi secara terus menerus dalam jangka panjang dan mampu mendorng pertumbuhan menghasilkan suatu kekuatan bagi kelanjutan pertumbuhan itu sendiri. Pertumbuhan ekonomi daerah dipengaruhi oleh tingkat permintaan barang dan jasa dari luar daerah (Priyasmini, 2016).

Tingkat pertumbuhan ekonomi dicirikan oleh pendapatan perkapita yang tinggi (Rice, 2010). Semakin tinggi pendapatan perkapita seseorang maka akan semakin tinggi pertumbuhan ekonomi di daerah tersebut. Peningkatan pertumbuhan ekonomi akan mempercepat pembangunan daerah. Sampai saat ini pertumbuhan ekonomi masih menjadi salah satu indikator keberhasilan dalam pembangunan, baik pembangunan nasional maupun regional. Pertumbuhan ekonomi dilihat berdasarkan perbedaan perkembangan produk domestik bruto (PDRB) tahun tertentu dengan tahun sebelumnya (Setiawan dan Handoko, 2006).

PDRB didukung oleh beberapa sektor terkait yang terdiri atas 17 sektor. Perkembangan PDRB berdasarkan lapangan 
usaha/sektor di Kabupaten Klungkung selama periode 2011-2016 dapat dilihat pada Tabel 3.

Tabel 3 menunjukkan bahwa bagaimana perkembangan PDRB Kabupaten Klungkung dari tahun 2012-2016. Besarnya PDRB Kabupaten Klungkung didukung oleh beberapa kompenen di dalamnya. Salah satu sektor yang memberikan kontribusi yang paling besar adalah sektor pertanian dan sektor perdagangan. Semakin besar nilai PDRB, dapat dikatakan suatu daerah/ wilayah semakin sejahtera atau makmur. Meskipun demikian tingginya PDRB tidak secara langsung menggambarkan tingginya pertumbuhan ekonomi disuatu daerah, karena PDRB merupakan angka agregat (rata-rata). Angka ini mengasumsikan semua penduduk memiliki akses yang sama terhadap pendapatan, sehingga kurang tepat dalam mencerminkan kesejahteraan.

Tidak seimbangnya transformasi structural akan menyebabkan terjadinya proses pemiskinan dan eksploitasi sumberdaya manusia pada sektor primer sehingga akan memicu terjadinya kelangkaan sumber daya alam. Tambunan (2001), menyatakan ketimpangan dalam pendistribusian pendapatan akan dipengaruhi oleh ketidakseimbangan antara pertumbuhan ekonomi dengan penyerapan tenaga kerja.

Ketimpangan yang terjadi dapat menciptakan suatu pertumbuhan ekonomi dengan peningkatan kemiskinan. Dalam upaya mempercepat pembangunan ekonomi di sauatu daerah perlu diketahui sektor-sektor utama yang potensial memberikan kontribusi bagi perekonomian dan pembangunan daerah. Oleh karena itu perlu dikaji lebih dalam mengenai analisis perubahan struktur ekonomi dan penyerapan tenaga kerja di Kabupaten Klungkung. Berdasarkan latar belakang di atas, maka tujuan penelitian ini adalah untuk menganalisis sektor potensial di Kabupaten Klungkung dilihat dari sisi Produk Domestik Regional Bruto (PDRB).

\section{METODE PENELITIAN}

Penelitian ini dilakukan di Kabupaten Klungkung. Alasan pemilihan Kabupaten
Klungkung sebagai lokasi penelitian adalah karena Kabupaten Klungkung merupakan salah satu kabupaten yang sedang mengalami perkembangan dalam hal perekonomian saat ini. Karenanya perlu adanya penelitian terkait sektor-sektor potensial yang dimiliki. Apabila sektor-sektor ekonomi tersebut sudah dapat diketahui, maka Kabupaten Klungkung akan lebih mudah dalam menentukan prioritas pembangunan di wilayahnya, dengan menjadikan sektor ekonomi tersebut sebagai penunjang petumbuhan ekonomi dan pembangunan di Kabupaten Klungkung.

Objek penelitian dalam penelitian ini adalah PDRB Kabupaten Klungkung atas dasar harga konstan menurut lapangan usaha tahun 2012-2016. Variabel pokok yang digunakan dalam penelitian ini adalah Produk Domestik Regional Bruto (PDRB) Kabupaten Klungkung atas dasar harga konstan menurut lapangan usaha tahun 2012-2016. Masingmasing sektor tersebut meliputi: Pertanian, Kehutanan, dan Perikanan, Pertambangan dan Penggalian, Industri Pengolahan, Pengadaan Listrik dan Gas, Pengadaan Air, Pengelolaan Sampah, Limbah dan Daur Ulang, Konstruksi, Perdagangan Besar dan Eceran; Reparasi Mobil dan Sepeda Motor, Transportasi dan Pergudangan, Penyediaan Akomodasi dan Makan Minum, Informasi dan Komunikasi, Jasa Keuangan dan Asuransi, Real Estate, Jasa Perusahaan, Administrasi Pemerintahan, Pertahanan dan Jaminan Sosial Wajib, Jasa Pendidikan, Jasa Kesehatan dan Kegiatan Sosial dan Jasa Lainnya.

Jenis data yang digunakan dalam penelitian ini adalah data kualitatif dan data kuantitatif. Data kualitatif dalam penelitian ini berkaitan dengan gambaran-gambaran umum mengenai kondisi wilayah Kabupaten Klungkung serta ulasan dari hasil penelitian sebelumnya. Data kuantitatif dalam penelitian ini adalah data PDRB Kabupaten Klungkung tahun 2011-2016 yang diperoleh dari Badan Pusat Statistik Provinsi Bali.

Data yang digunakan dalam penelitian ini adalah data sekunder. Data sekunder adalah data berupa dokumen-dokumen ataupun catatan-catatan yang telah diolah oleh pihak- 
pihak terkait sehingga dapat digunakan untuk kepentingan analisis (Sugiyono, 2013). Data sekunder dalam penelitian ini yaitu data PDRB Kabupaten Klungkung tahun 2011-2016 yang diperoleh dari Badan Pusat Statistik Provinsi Bali.

Metode pengumpulan data yang digunakan dalam penelitian ini adalah observasi non partisipan, dimana peneliti tidak terlibat dan hanya sebagai pengamat independen (Sugiyono, 2013:204). Data yang dikumpulkan melalui metode ini adalah dengan cara melakukan pengamatan dan mencatat serta mempelajari uraian-uraian dari bukubuku, jurnal-jurnal, skripsi dan mengakses data dari perpustakaan Badan Pusat Statistik Provinsi Bali.

Teknik analisis yang digunakan untuk mengetahui ektor potensial yang dapat dikembangkan di Kabupaten Klungkung maka digunakan analisis Location Quetient, Analisis Growth Ratio Model dan analisis Overlay.

\section{Analisis Location Quotient (LQ)}

Teknik Location Quetient atau disingkat LQ ini digunakan untuk mengetahui sektor yang menjadi sektor prioritas atau potensial dan sektor non potensial. Menurut Aziz (1993:231-232), metode LQ menghasilkan dua klasifikassi penting yaitu sektor basis dan non basis, serta terfokus pada substitusi impor yang potensial atau produk dengan potensi ekspansi ekspor dan pengaruh eksternal (Cubukcu, 2011). Untuk mengidentifikasi sektor basis dan non basis perekonomian adalah dengan menggunakan rumus sebagai berikut (Zheng, 2013):

$$
\mathrm{LQx}=\frac{\mathrm{vix} / \mathrm{vt}}{\mathrm{Vix} / \mathrm{Vt}}
$$

Keterangan :

LQx :Sektor potensial di wilayah Kabupaten Klungkung

vix :Pendapatan dari sektor $\mathrm{x}$ di wilayah Kabupaten Klungkung

vt :Pendapatan total dari wilayah Kabupaten Klungkung

Vix :Pendapatan dari sektor $\mathrm{x}$ di wilayah Provinsi Bali
$\mathrm{Vt}$ :Pendapatan total dari wilayah Provinsi Bali

\section{Analisis Growth Ratio Model}

Analisis GRM merupakan alat analisis untuk melihat deskripsi kegiatan atau sektor ekonomi yang potensial berdasarkan pada kriteria pertumbuhan struktur ekonomi wilayah baik eksternal maupun internal. Pendekatan analisis GRM dibagi menjadi dua rasio, yaitu :

1) Rasio Pertumbuhan Wilayah Studi (RPs) adalah perbandingan antara laju pertumbuhan pendapatan kegiatan sektor i di wilayah studi dengan laju pertumbuhan total kegiatan (PDRB) wilayah referensi.

Formula :

$R P s=\frac{\Delta \text { Eij/Eij }(t)}{\Delta \text { Eir } / E \text { ir }(\mathrm{t})}$

\section{Keterangan:}

$\Delta$ Eij $=$ Perubahan PDRB sektor i diwilayah Kabupaten Klungkung

Eij (t) =PDRB sektor i pada awal periode penelitian di Kabupaten Klungkung

$\Delta$ Eir $=$ Perubahan PDRB sektor i di Provinsi Bali

Eir $(\mathrm{t})=$ PDRB sektor i awal periode penelitian di Provinsi Bali

Jika nilai RPs $>1$ P positif $(+)$, artinya menunjukkan bahwa pertumbuhan sektor pada tingkat wilayah studi lebih tinggi dibandingkan dengan pertumbuhan sektor pada wilayah referensi. Jika nilai RPs $<1 \mathrm{P}$ negatif (-), artinya pertumbuhan suatu sektor pada tingkat wilayah studi lebih rendah dibandingkan dengan pertumbuhan sektor tersebut pada wilayah referensi.

2) Rasio Pertumbuhan Wilayah Referensi (RPr) adalah perbandingan antara laju pertumbuhan kegiatan sektor i di wilayah referensi dengan laju pertumbuhan kegiatan i wilayah referensi.

Formula:

$\operatorname{RPr}=\Delta \operatorname{Eir} / \operatorname{Eir}(\mathrm{t})$

$$
\overline{\Delta \mathrm{Er} / \mathrm{Er}(\mathrm{t})}
$$

Keterangan:

$\Delta$ Eir $=$ Perubahan PDRB sektor i di wilayah Provinsi

Eir $(\mathrm{t})=$ PDRB sektor i pada awal periode Provinsi 
Tabel 4 Hasil Perhitungan dengan Analisis Location Quotient PDRB Kabu paten Klungkung Tahun 2012-2016

\begin{tabular}{|c|c|c|c|c|c|c|c|}
\hline Lapangan Usaha/Sektor & 2012 & 2013 & 2014 & 2015 & 2016 & Rata-Rata LQ & Ket. \\
\hline $\begin{array}{l}\text { Pertanian, Kehutanan, dan } \\
\text { Perikanan }\end{array}$ & 1,53 & 1,54 & 1,55 & 1,59 & 1,56 & 1,55 & Basis \\
\hline $\begin{array}{l}\text { Pertambangan dan } \\
\text { Penggalian }\end{array}$ & 3,87 & 3,88 & 3,90 & 3,86 & 3,53 & 3,81 & Basis \\
\hline Industri Pengolahan & 1,34 & 1,35 & 1,35 & 1,35 & 1,40 & 1,36 & Basis \\
\hline Pengadaan Listrik dan Gas & 0,53 & 0,58 & 0,54 & 0,55 & 0,45 & 0,53 & Non-Basis \\
\hline $\begin{array}{l}\text { Pengadaan Air, Pengelolaan } \\
\text { Sampah, Limbah dan Daur } \\
\text { Ulang }\end{array}$ & 1,16 & 1,10 & 1,11 & 1,11 & 0,98 & 1,09 & Basis \\
\hline Konstruksi & 0,90 & 0,91 & 0,90 & 0,92 & 0,98 & 0,92 & Non Basis \\
\hline $\begin{array}{l}\text { Perdagangan Besar dan } \\
\text { Eceran; Reparasi Mobil dan } \\
\text { Sepeda Motor }\end{array}$ & 0,91 & 0,91 & 0,91 & 0,90 & 0,91 & 0,91 & Non-Basis \\
\hline $\begin{array}{l}\text { Transportasi dan } \\
\text { Pergudangan }\end{array}$ & 0,38 & 0,38 & 0,39 & 0,40 & 0,39 & 0,39 & Non-Basis \\
\hline $\begin{array}{l}\text { Penyediaan Akomodasi dan } \\
\text { Makan Minum }\end{array}$ & 0,52 & 0,53 & 0,52 & 0,52 & 0,54 & 0,53 & Non-Basis \\
\hline Informasi dan Komunikasi & 1,62 & 1,63 & 1,63 & 1,58 & 1,58 & 1,61 & Basis \\
\hline Jasa Keuangan dan Asuransi & 0,91 & 0,91 & 0,92 & 0,94 & 0,95 & 0,92 & Non-Basis \\
\hline Real Estate & 0,57 & 0,57 & 0,57 & 0,57 & 0,57 & 0,57 & Non-Basis \\
\hline Jasa Perusahaan & 0,93 & 0,94 & 0,94 & 0,94 & 0,92 & 0,93 & Non-Basis \\
\hline $\begin{array}{l}\text { Administrasi Pemerintahan, } \\
\text { Pertahanan dan Jaminan } \\
\text { Sosial Wajib }\end{array}$ & 0,98 & 0,99 & 0,99 & 1,00 & 1,01 & 1,00 & Non-Basis \\
\hline Jasa Pendidikan & 0,44 & 0,44 & 0,44 & 0,46 & 0,45 & 0,45 & Non-Basis \\
\hline $\begin{array}{l}\text { Jasa Kesehatan dan } \\
\text { Kegiatan Sosial }\end{array}$ & 1,89 & 1,91 & 1,91 & 1,96 & 1,95 & 1,92 & Basis \\
\hline Jasa Lainnya & 1,39 & 1,39 & 1,41 & 1,39 & 1,39 & 1,40 & Basis \\
\hline
\end{tabular}

$\Delta \mathrm{Er}=$ Perubahan total PDRB sektor $\mathrm{i}$ diwilayah Provinsi

E $r(\mathrm{t})=$ Total PDRB sektor $\mathrm{i}$ pada awal periode penelitian wilayah Provinsi

Jika nilai $\mathrm{RPr}>1$ P positif $(+)$, artinya menunjukkan bahwa pertumbuhan suatu sektor i dalam wilayah referensi lebih tinggi dari pertumbuhan PDRB total wilayah referensi. Jika nilai $\operatorname{RPr}<1$ P negative (-), artinya menunjukkan bahwa pertumbuhan suatu sektor i dalam wilayah referensi lebih kecil dari pertumbuhan PDRB total wilayah referensi.

\section{Analisis Overlay}

Analisis Overlay dilakukan untuk melihat deskripsi kegiatan ekonomi yang potensial dikembangkan di Kabupaten Klungkung, berdasarkan kriteria pertumbuhan dan kriteria kontribusi. Dalam hal ini teknik Overlay dilakukan untuk menunjukkan hasil kombinasi analisis LQ dan MRP, setiap sektor diklasifikasikan menjadi 4 tipe, yaitu:

1) Pertumbuhan +, kontribusi +, menunjukkan suatu kegiatan yang sangat baik dari pertumbuhan maupun kontribusi.

2) Pertumbuhan + , kontribusi -, menunjukkan bahwa pertumbuhan baik, kontribusinya kecil, kegiatan ini dapat ditingkatkan kontribusinya untuk dipacu menjadi kegiatan yang potensial. 3) Pertumbuhan -, kontribusi +, menunjukkan bahwa kegiatan ini sangat memungkinkan merupakan kegiatan yang sedang mengalami penurunan.

4) Pertumbuhan -, kontribusi -, menunjukkan bahwa kegiatan ini tidak potensial.

\section{HASIL DAN PEMBAHASAN Analisis Location Quotient (LQ)}

Teknik analisis dengan LQ ini digunakan untuk mengetahui sektor potensial 
Tabel 5 Hasil Analisis Model Rasio Pertumbuhan Kabupaten Klungkung Tahun 2012-2016

\begin{tabular}{|c|c|c|c|c|}
\hline \multirow[t]{2}{*}{ Lapangan Usaha/Sektor } & \multicolumn{2}{|c|}{ RPr } & \multicolumn{2}{|c|}{ RPs } \\
\hline & Nilai & Tanda & Nilai & Tanda \\
\hline $\begin{array}{l}\text { Pertanian, Kehutanan, dan } \\
\text { Perikanan }\end{array}$ & 0,49 & - & 0,52 & - \\
\hline Pertambangan dan Penggalian & 0,15 & - & 0,27 & - \\
\hline Industri Pengolahan & 1,08 & + & 1,21 & + \\
\hline Pengadaan Listrik dan Gas & 1,02 & + & 0,34 & - \\
\hline $\begin{array}{l}\text { Pengadaan Air, Pengelolaan } \\
\text { Sampah, Limbah dan Daur Ulang }\end{array}$ & 0,81 & - & 0,10 & - \\
\hline Konstruksi & 0,79 & - & 1,10 & + \\
\hline $\begin{array}{l}\text { Perdagangan Besar dan Eceran; } \\
\text { Reparasi Mobil dan Sepeda Motor }\end{array}$ & 1,20 & + & 1,13 & + \\
\hline Transportasi dan Pergudangan & 0,97 & - & 1,03 & + \\
\hline $\begin{array}{l}\text { Penyediaan Akomodasi dan Makan } \\
\text { Minum }\end{array}$ & 1,07 & + & 1,15 & + \\
\hline Informasi dan Komunikasi & 1,24 & + & 1,06 & + \\
\hline Jasa Keuangan dan Asuransi & 1,38 & - & 1,52 & + \\
\hline Real Estate & 0,99 & - & 0,99 & - \\
\hline Jasa Perusahaan & 1,18 & + & 1,08 & + \\
\hline $\begin{array}{l}\text { Administrasi Pemerintahan, } \\
\text { Pertahanan dan Jaminan Sosial Wajib }\end{array}$ & 0,96 & - & 1,04 & + \\
\hline Jasa Pendidikan & 1,62 & + & 1,65 & + \\
\hline $\begin{array}{l}\text { Jasa Kesehatan dan Kegiatan } \\
\text { Sosial }\end{array}$ & 1,66 & + & 1,75 & + \\
\hline Jasa Lainnya & 1,11 & + & 1,03 & + \\
\hline
\end{tabular}

di Kabupaten Klungkung dari segi kontribusi masing-masing sektor pada wilayah tersebut. Keseluruhan sektor ekonomi ini mengalami fluktuasi dari tahun 2012-2016. Dari hasil perhitungan pada Tabel 4 dengan menggunakan analisis Location Quotient, terdapat tujuh sektor potensial yang memiliki rata-rata LQ lebih besar dari satu, yaitu: (1) Sektor Pertanian, Kehutanan, dan Perikanan, (2) Pertambangan dan Penggalian, (3) Industri Pengolahan, (4) Pengadaan Air, Pengelolaan Sampah, Limbah dan Daur Ulang, (5) Informasi dan Komunikasi, (6) Jasa Kesehatan dan Kegiatan Sosial, dan (7) Jasa Lainnya. Hasil ini menujukkan bahwa sektor tersebut termasuk sektor basis atau menjadi sumber pertumbuhan, artinya sektor tersebut mampu menghasilkan kebutuhan lebih dari yang diharapkan untuk perekonomian di wilayahnya dan akan mampu menjadi sektor atau industri ekspor (Thomas, 1998).
Sektor Pertanian, Kehutanan, dan Perikanan, masih memberikan kontribusi yang terbesar dalam pertumbuhan ekonomi atau PDRB Kabupaten Klungkung. Oleh karena itu, sektor ini cukup potensial untuk dikembangkan sehingga kontribusinya bagi perekonomian Kabupaten Klungkung bisa semakin ditingkatkan di masa akan datang. Sektor pertambangan dan penggalian merupakan sektor yang mempunyai rata-rata LQ paling besar diabndingkan sektor-sektor lainnya. Hal ini terjadi karena Kabupaten Klungkung merupakan salah satu dari daerah dengan sektor galian $\mathrm{C}$ yang berkembang cukup pesat. Tetapi mulai tahun 2017 galian C mulai di tutup, sehingga kedepannya galian $\mathrm{C}$ bukan lagi menjadi sektor yang potensial.

Sektor Industri Pengolahan merupakan sektor yang potensial untuk dikembangkan. Hal ini karena sektor ini memberikan nilai tambah terbesar di antara sembilan sektor 
ekonomi lainnya, perkembangan tersebut sejalan dengan meningkatnya permintaan akan produk barang jadi atau setengah jadi baik domestik maupun internasional. Saat ini sektor industri dijadikan sebagai prioritas pembangunan yang diharapkan mempunyai peranan sebagai leading sector atau sektor pemimpin bagi pembangunan sektor-sektor lainnya.

Sektor Pengadaan Air, Pengelolaan Sampah, Limbah dan Daur Ulang merupakan; Informasi dan Komunikasi; Jasa Kesehatan dan Kegiatan Sosial, dan Jasa Lainnya merupakan sektor-sektor yang juga potensial dikembangkan. Hal ini karena ditengah perkembangan zaman keberadaan sektorsektor ini sangat penting untuk mendukung pertumbuhan ekonomi yang inklusif.

\section{Analisis Growth Ratio Model}

Analisis GRM merupakan alat analisis untuk melihat deskripsi kegiatan atau sektor ekonomi yang potensial berdasarkan pada kriteria pertumbuhan struktur ekonomi wilayah baik eksternal maupun internal. Analisis model rasio pertumbuhan (MRP) merupakan salah satu alat analisis alternatif guna mendukung penentuan deskripsi kegiatan ekonomi yang potensial. MRP ini serupa dengan LQ, perbedaanya terletak pada cara menghitung. Analisis LQ menggunakan distribusi PDRB, sedangkan MRP menggunakan kriteria pertumbuhan.

Dari hasil analisis LQ sebelumnya diperoleh 7 sektor basis di Kabupaten Klungkung dilihat dari sisi kontribusi. Dalam analisis MRP ini akan dilanjutkan terhadap pertumbuhan keempat sektor tersebut dan sub sektornya.

Berdasarkan Tabel 5 dapat dilihat bahwa dari 7 sektor basis dalam analisis LQ, terdapat 4 sektor basis yang memiliki nilai RPr dan RPs positif yaitu: (1) sektor industri pengolahan; (2) informasi dan komunikasi; (3) jasa kesehatan dan kegiatan sosial dan (4) jasa lainnya. Hasil ini memiliki arti bahwa sektor tersebut memiliki pertumbuhan yang menonjol baik di propinsi Bali maupun Kabupaten Klungkung, sektor ini disebut sebagai potensial pertumbuhan. Jika dilihat secara keseluruhan hasil analisis menujukkan bahwa 4 dari sektor non basis juga memiliki nilai RPr + dan RPs + yaitu (1) sektor perdagangan besar dan eceran, reparasi mobil dan sepeda motor, (2) penyediaan akomodasi dan makanan minuman; (3) jasa perusahaan dan (4) jasa pendidikan.

Untuk RPr + dan RPs - adalah sektor (1) pengadaan listrik dan gas, serta (2) pengadaan air, pengelolaan sampah dan daur ulang. Hasi ini menujukkan bahwa pertumbuhan sektoral pada tingkat Kabupaten Klungkung lebih tinggi dari pertumbuhan sektor pada wilayah Bali. Sektor dengan RPr - dan RPs + adalah sektor (1) konstruksi; (2) transportasi dan pergudangan; (3) jasa keuangan dan asuransi; dan (4) administrasi pemerintahan, pertanahan dan jaminan sosial wajib. Hasil ini menujukkan bahwa pertumbuhan sektoral di Kabupaten Klungkung lebih rendah dibandingkan dengan pertumbuhan sektor pada wilayah Provinsi Bali, begitu juga dengan kontribusi sektoral di Kabupaten Klungkung lebih rendah dari Provinsi Bali.

Sektor industri pengolahan; informasi dan komunikasi; jasa kesehatan dan kegiatan sosial dan jasa lainnya, merupakan sektor yang potensial untuk dikembangkan. Industrialisasi memiliki peran strategis untuk mendukung pertumbuhan ekonomi yang cukup tinggi secara berkelanjutan dan meningkatkan produksi fisik masyarakat melalui perluasan lapangan usaha dan memperluas kesempatan kerja, meningkatkan serta menghemat devisa, mendorong pembangunan daerah, meningkatkan dan meratakan pendapatan masyarakat serta mengentaskan masyarakat dari kemiskinan. Pertumbuhan sektor industri pengolahan memiliki peran penting dalam peningkatan kinerja perekonomian di Kabupaten Klungkung. Sebagai fasilitas penopang maka keberadaan sektor informasi dan komunikasi sangat penting untuk peningaktan perekonomian daerah. Karena dengan adanya informasi dan komunikasi maka lalu lintas perekonomian akan menjadi lebih mudah. Sealin itu keberadaan sektor jasa kesehatan dan kegiatan sosial dan jasa lainnya juga potensial untuk dikembangkan di 
Kabupaten Klungkung.

Berdasarkan Tabel 5 dapat dilihat bahwa dari 7 sektor basis dalam analisis LQ, terdapat 4 sektor basis yang memiliki nilai RPr dan RPs positif yaitu: (1) sektor industri pengolahan; (2) informasi dan komunikasi; (3) jasa kesehatan dan kegiatan sosial dan (4) jasa lainnya. Hasil ini memiliki arti bahwa sektor tersebut memiliki pertumbuhan yang menonjol baik di propinsi Bali maupun Kabupaten Klungkung, sektor ini disebut sebagai potensial pertumbuhan. Jika dilihat secara keseluruhan hasil analisis menujukkan bahwa 4 dari sektor non basis juga memiliki nilai $\mathrm{RPr}+$ dan RPS + yaitu (1) sektor perdagangan besar dan eceran, reparasi mobil dan sepeda motor, (2) penyediaan akomodasi dan makanan minuman; (3) jasa perusahaan dan (4) jasa pendidikan.

Untuk RPr + dan RPs - adalah sektor (1) pengadaan listrik dan gas, serta (2) pengadaan air, pengelolaan sampah dan daur ulang. Hasi ini menujukkan bahwa pertumbuhan sektoral pada tingkat Kabupaten Klungkung lebih tinggi dari pertumbuhan sektor pada wilayah Bali. Sektor dengan RPr - dan RPs + adalah sektor (1) konstruksi; (2) transportasi dan pergudangan; (3) jasa keuangan dan asuransi; dan (4) administrasi pemerintahan, pertanahan dan jaminan sosial wajib. Hasil ini menujukkan bahwa pertumbuhan sektoral di Kabupaten Klungkung lebih rendah dibandingkan dengan pertumbuhan sektor pada wilayah Provinsi Bali, begitu juga dengan kontribusi sektoral di Kabupaten Klungkung lebih rendah dari Provinsi Bali.

Sektor industri pengolahan; informasi dan komunikasi; jasa kesehatan dan kegiatan sosial dan jasa lainnya, merupakan sektor yang potensial untuk dikembangkan. Industrialisasi memiliki peran strategis untuk mendukung pertumbuhan ekonomi yang cukup tinggi secara berkelanjutan dan meningkatkan produksi fisik masyarakat melalui perluasan lapangan usaha dan memperluas kesempatan kerja, meningkatkan serta menghemat devisa, mendorong pembangunan daerah, meningkatkan dan meratakan pendapatan masyarakat serta mengentaskan masyarakat dari kemiskinan. Pertumbuhan sektor industri pengolahan memiliki peran penting dalam peningkatan kinerja perekonomian di Kabupaten Klungkung. Sebagai fasilitas penopang maka keberadaan sektor informasi dan komunikasi sangat penting untuk peningaktan perekonomian daerah. Karena dengan adanya informasi dan komunikasi maka lalu lintas perekonomian akan menjadi lebih mudah. Sealin itu keberadaan sektor jasa kesehatan dan kegiatan sosial dan jasa lainnya juga potensial untuk dikembangkan di Kabupaten Klungkung.

\section{Analisis Overlay}

Analisis Overlay dilakukan untuk melihat deskripsi kegiatan ekonomi yang potensial dikembangkan di Kabupaten Klungkung, berdasarkan kriteria pertumbuhan dan kriteria kontribusi. Metode ini mempunyai penilaian terhadap sekto-sektor ekonomi yang potensial berdasarkan kriteria pertumbuhan dan kriteria kontribusi. Hasil analisis Overlay Kabupeten Klungkung tahun 2012-2016 ditujukkan pada Tabel 6.

Berdasarkan Tabel 6 hasil perhitungan analisis Overlay untuk Kabupaten Klungkung dapat dikelompokkan menjadi sebagai berikut:

1) Sektor industri pengolahan; informasi dan komunikasi; jasa kesehatan dan kegiatan sosial; dan jasa lainnya merupakan sektor yang basis atau potensial karena mempunyai tingkat pertumbuhan yang positif dan memberikan kontribusi yang besar dalam PDRB Kabupaten Klungkung.

2) Sektor pertanian, kehutanan dan perikanan; pertambangan dan penggalian; dan pengadaan air, pengelolaan sampah, limbah dan daur ulang termasuk dalam sektor yang memberikan kontribusi yang besar atau potensial tetapi dengan tingkat pertumbuhan yang kecil.

3) Sektor konstruksi; perdagangan besar dan eceran, resparasi mobil dan sepeda motor; transportasi dan pergudangan; penyediaan akomodasi dan makan minum; jasa keuangan dan asuransi; jasa perusahaan; administrasi pemerintahan, pertanahan dan jaminan sosial wajib; dan jasa pendidikan merupakan sektor dengan tingkat pertumbuhan yang potensial 
Tabel 6 Hasil Analisis Overlay Kabupaten Klungkung Tahun 2012-2016

\begin{tabular}{|c|c|c|c|c|c|}
\hline \multirow[t]{2}{*}{ Lapangan Usaha/Sektor } & \multicolumn{2}{|c|}{ LQ (kontribusi) } & \multicolumn{2}{|c|}{ MRP (pertumbuhan) } & \multirow[t]{2}{*}{ Overlay } \\
\hline & Nilai & Tanda & Nilai & Tanda & \\
\hline $\begin{array}{l}\text { Pertanian, Kehutanan, dan } \\
\text { Perikanan }\end{array}$ & 1,55 & + & 0,52 & - & +- \\
\hline $\begin{array}{l}\text { Pertambangan dan } \\
\text { Penggalian }\end{array}$ & 3,81 & + & 0,27 & - & +- \\
\hline Industri Pengolahan & 1,36 & + & 1,21 & + & ++ \\
\hline Pengadaan Listrik dan Gas & 0,53 & - & 0,34 & - & -- \\
\hline $\begin{array}{l}\text { Pengadaan Air, } \\
\text { Pengelolaan Sampah, } \\
\text { Limbah dan Daur Ulang }\end{array}$ & 1,09 & + & 0,10 & - & +- \\
\hline Konstruksi & 0,92 & - & 1,10 & + & -+ \\
\hline $\begin{array}{l}\text { Perdagangan Besar dan Eceran; } \\
\text { Reparasi Mobil dan Sepeda } \\
\text { Motor }\end{array}$ & 0,91 & - & 1,13 & + & -+ \\
\hline $\begin{array}{l}\text { Transportasi dan } \\
\text { Pergudangan }\end{array}$ & 0,39 & - & 1,03 & + & -+ \\
\hline $\begin{array}{l}\text { Penyediaan Akomodasi dan } \\
\text { Makan Minum }\end{array}$ & 0,53 & - & 1,15 & + & -+ \\
\hline Informasi dan Komunikasi & 1,61 & + & 1,06 & + & ++ \\
\hline Jasa Keuangan dan Asuransi & 0,92 & - & 1,52 & + & -+ \\
\hline Real Estate & 0,57 & - & 0,99 & - & -- \\
\hline Jasa Perusahaan & 0,93 & - & 1,08 & + & -+ \\
\hline $\begin{array}{l}\text { Administrasi Pemerintahan, } \\
\text { Pertahanan dan Jaminan Sosial } \\
\text { Wajib }\end{array}$ & 1,00 & - & 1,04 & + & -+ \\
\hline Jasa Pendidikan & 0,45 & - & 1,65 & + & -+ \\
\hline $\begin{array}{l}\text { Jasa Kesehatan dan Kegiatan } \\
\text { Sosial }\end{array}$ & 1,92 & + & 1,75 & + & ++ \\
\hline Jasa Lainnya & 1,40 & + & 1,03 & + & ++ \\
\hline
\end{tabular}

Sumber : Data diolah, 2018

tetapi kontribusi kecil terhadap PDRB Kabupaten Klungkung.

4) Sektor pengadaan listrik dan gas; dan real estate termasuk sektor yang tidak potensial di daerah Kabupaten Klungkung.

Sektor industri pengolahan; informasi dan komunikasi; jasa kesehatan dan kegiatan sosial; dan jasa lainnya yang berpotensi dikembangkan di Kabupaten Klungkung dalam periode tahun 2012-2016 mencerminkan pertumbuhan yang cukup signifikan. Peningkatan pertumbuhan dari sektor industri pengolahan disebabkan karena sektor industri dianggap sebagai the leading sector yang mampu mendorong berkembangnya sektor-sektor yang lain, seperti sektor jasa dan pertanian (Peneder, 2003). Struktur perekonomian suatu wilayah

yang relatif maju ditandai oleh semakin besarnya peran sektor industri pengolahan dan jasa dalam menopang perekonomian wilayah tersebut (Saerofi, 2005).

Sektor ini telah menggantikan peran sektor tradisional (pertanian) dalam penyerapan tenaga kerja dan sumber pendapatan wilayah (Schaffer, 2010). Menurut Badan Pusat Statistik (BPS), Industri Pengolahan adalah suatu kegiatan ekonomi yang melakukan kegiatan mengubah suatu barang dasar secara mekanis, kimia, atau dengan tangan sehingga menjadi barang jadi/setengah jadi, dan atau barang yang kurang nilainya menjadi barang yang lebih tinggi nilainya, dan sifatnya lebih dekat kepada pemakai akhir. Jika sektor ini dikembangkan sebagai sektor potensial/basis diharapkan dapat menunjang pertumbuhan 
sektor-sektor lainnya sehingga kontribusi terhadap PDRB Kabupaten Klungkung dapat lebih meningkat dan sektor potensial di Kabupaten Klungkung juga lebih beragam di masa mendatang.

Keberadaan sektor industri pengolahan memiliki peran strategis untuk mendukung pertumbuhan ekonomi yang cukup tinggi secara berkelanjutan dan meningkatkan produksi fisik masyarakat melalui perluasan lapangan usaha dan memperluas kesempatan kerja, meningkatkan serta menghemat devisa, mendorong pembangunan daerah, meningkatkan dan meratakan pendapatan masyarakat serta mengentaskan masyarakat dari kemiskinan. Dalam sektor produksi mekanisme pendorong pembangunan (inducement mechanisme) yang tercipta sebagai akibat dari adanya hubungan antara berbagai industri dalam menyediakan barangbarang yang dipergunakan sebagai bahan baku bagi industri lainnya. Dalam pengembangan sektor industri pengolahan sebagai sektor potensial Kabupaten Klungkung terhambat oleh masalah keterbatasan ketersediaan SDA, SDM dan lain sebagainya

Untuk sektor informasi dan komunikasi yang memiliki nilai pertmbuhan dan kontribusi yang positif dalam periode tahun 2012-2016. Di Kabupaten Klungkung saat ini banyak berkembang usaha-usaha di bidang informasi dan komunikasi. Hal ini terjadi di dukung oleh pesatnya perkembangan era digital yang menyebabkan teknologi informasi dan komunikais menjadi salah satu kebutuhan utama dalam menunjang kehidupan manusia, terutama dalam mengakses informasi terkait dengan upaya memejukan usaha. Sektor ini diharapkan dapat menunjang pertumbuhan sektor-sektor lainnya sehingga kontribusi terhadap PDRB Kabupaten Klungkung dapat lebih meningkat. Tantangan yang dihadapi dalam pengembangan sektor informasi dan komunikasi adalah masih terbatasnya kualitas SDM dan penguasaan teknologi sehingga belum mampu bersaing secara lebih optimal.

Untuk sektor jasa kesehatan dan kegaitan sosial yang memiliki nilai LQ positif dalam periode tahun 2012-2016 menunjukkan pertumbuhan yang positif juga. Sektor jasa kesehatan dan kegaitan sosial telahberkembang dengan potensial di Kabupaten Klungkung dan dapat menunjang pertumbuhan sektor-sektor lainnya sehingga kontribusi terhadap PDRB Kabupaten Klungkung dapat lebih meningkat. Sektor jasa lainnya juga memiliki nilai pertumbuhan dan kontribusi positif dalam periode tahun 2012-2016. Dari sub sektor yang lebih potensial menyumbang yaitu sub sektor swasta. Di Kabupaten Klungkung saat ini banyak berkembang usaha-usaha swasta di bidang jasa seperti : salon, bengkel, kios-kios pembayaran listrik online. Tantangan yang dihadapi dalam pengembangan sektor jasajasa adalah masih kurangnya kualitas SDM dan penguasaan teknologi sehingga jasa-jasa yang dihasilkan cenderung monoton dan belum mampu bersaing dengan para pelaku jasa di daerah lain.

Meskipun demikian ekonomi wilayah sebaiknya tidak berbasis satu sektor tertentu. Keanekaragaman ekonomi diperlukan untuk mempertahankan lapangan pekerjaan dan untuk menstabilkan ekonomi wilayah. Ekonomi yang beragam lebih mampu bertahan terhadap konjungtur ekonomi. Secara umum perencana pembangunan seharusnya dapat memprediksikan arah pembangunan yang akan berlangsung sehingga dapat dibuat sarana umum yang baru untuk menunjang kegiatan masyarakat pada wilayah tersebut. Penyediaan sarana dapat juga dilakukan dengan memberikan potongan pajak dan ongkos kompensasi berupa pengelolaan sarana umum kepada sektor swasta yang bersedia membangun fasilitas umum.

Pemerintah daerah dan pengusaha adalah dua kelompok yang paling berpengaruh dalam menentukan corak pertumbuhan ekonomi daerah. Pemerintah daerah, mempunyai kelebihan dalam satu hal, dan tentu saja keterbatasan dalam hal lain, demikian juga pengusaha. Sinergi antara keduanya untuk merencanakan bagaimana ekonomi daerah akan diarahkan perlu menjadi pemahaman bersama. Pemerintah memiliki kesempatan membuat berbagai peraturan, menyediakan berbagai sarana dan peluang, 
serta membentuk wawasan orang banyak. Tetapi pemerintah daerah tidak mengetahui banyak bagaimana proses kegiatan ekonomi sebenarnya berlangsung. Pengusaha mempunyai kemampuan mengenali kebutuhan orang banyak dan dengan berbagai insiatifnya, memenuhi kebutuhan itu. Aktivitas memenuhi kebutuhan itu membuat roda perekonomian berputar, menghasilkan gaji dan upah bagi pekerja dan pajak bagi pemerintah.

Dalam mempertahankan keberlanjutan pembangunan ekonomi daerah perlu di perhatikan agar membawa dampak yang menguntungkan bagi penduduk daerah perlu memahami bahwa perencanaan pembangunan daerah dapat memberikan pengaruh yang baik guna mencapai tujuan pembangunan ekonomi yang diharapkan. Bila kebijakan perencanaan pembangunan tidak tepat sasaran maka akan mengakibatkan perlambatan laju pertumbuhan ekonomi. Maka perencanaan pembangunan daerah mempunyai potensi untuk meningkatkan pembangunan ekonomi serta menciptakan peluang peluang bisnis diberbagai sektor yang menguntungkan dalam mempercepat laju pertumbuhan ekonomi daerah.

\section{SIMPULAN}

Berdasarkan hasil analisis maka dapat disimpulkan bahwa sektor yang potensial di Kabupaten Klungkung selama periode tahun 2012-2016 terdapat 4 sektor yaitu (1) sektor industri pengolahan; (2) informasi dan komunikasi; (3) jasa kesehatan dan kegiatan sosial; dan (4) jasa lainnya. Hal ini dilihat dari hasil analisis yang menujukkan bahwa untuk keempat sektor ini memiliki tingkat pertumbuhan yang positif dan memberikan kontribusi yang besar dalam PDRB Kabupaten Klungkung.

\section{SARAN}

Saran yang dapat diberikan adalah di Kabupaten Klungkung masih terdapat beberapa sektor yang kurang potensial, sehingga pemerintah sebaiknya membuat beberapa kebijakan untuk meningkatkan kinerja dari sektor-sektor tersebut dengan cara memberikan rangsangan dalam bentuk modal. Dengan adanya modal, dalam hal ini seperti pinjaman kredit maupun subsidi sehingga nantinya sektor-sektor yang belum potensial ini dapat berkembang menjadi sektor yang potensial. Pemerintah Kabupaten Klungkung diharapkan dapat meningkatkan kualitas SDM yang dimiliki untuk menunjang perkembangan sektor ekonomi yang dimiliki dan kualitas SDM yang baik akan membuat tenaga kerja yang ada mampu bersaing dan dapat diserap oleh pasar sehingga mengurangi pengangguran.

\section{REFERENSI}

Adipuryanti, Ni Luh Putu Yuni., dan I Ketut Sudibia. 2015. Analisis Pengaruh Jumlah Penduduk Yang Bekerja Dan Investasi Terhadap Ketimpangan Distribusi Pendapatan Melalui Pertumbuhan Ekonomi Kabupaten/ Kota Di Provinsi Bali. PIRAMIDA Vol. XI No. $1: 20-28$.

Adisasmita, R 2008. Ekonomi Archipelago. Yogyakarta. Graha Ilmu.

Afzal, M. 2007. The Impact Of Globalisation On Economic Growth Of Pakistan. The Pakistan and economic growth in Ghana. International research journal of finance and economics. pp 723-734.

Al-Habees, Mahmoud A and Mohammed Abu Rumman. 2012. The Relationship Between Unemployment and Economic Growth in Jordan and Some Arab Countries. World Applied Sciences Journal. Vol.18, No.5

Altiner, Res Assist Ali. 2012. Foreign Direct Investment And Gross Domestic Product: An Application On Eco Region (1995-2011). International journal of business and social science 3.22 .

Andrea Ascani, Riccardo Crescenzi \& Simona Iammarino. 2012. Regional Economic 
Development: A Review. London School of Economics and Political Science. 1 (3) pp: 2-26

Anissa Nurfatimah. 2013. Analisis Potensi Pertumbuhan Ekonomi Kabupaten/ Kota di Provinsi Bali. Jurnal Imliah. Jurusan IESP Fakultas Ekonomi dan Bisnis Universitas Islam Negeri Syarif Hidayatullah Jakarta.

Artana Yasa, I Komang Oka; Arka, Sudarsana. Pengaruh Pertumbuhan Ekonomi Dan Disparitas Pendapatan Antardaerah Terhadap Kesejahteraan Masyarakat Provinsi Bali. Jurnal Ekonomi Kuantitatif Terapan, [S.1.], nov. 2015. ISSN 2303-0186. Available at: $<$ https://ojs.unud.ac.id/index. php/jekt/article/view/16494>. Date accessed: 24 nov. 2018. doi: https:// doi.org/10.24843/JEKT.2015. v08.i01.p07.

Arsyad, Lincolin. 2010. Ekonomi Pembangunan, EdisiKelima. Yogyakarta: STIE YKPN.

Aziz, Iwan Jaya. 1993. Beberapa Aspek Dalam Pembangunan Ekonomi Regional. BPFE UGM. Yogyakarta.

Cubukcu, K.Mert. 2011. The Spatial Distribution of Economic Base Multipliers: A GIS and Spatial Statistics-Based Cluster Analysis. Journal Department of City and Regional Planning DokuzEylul University Izmir Tukey, 8(2), pp:49-62.

Dayuh Rimbawan, Nyoman. 2010. Pertumbuhan Ekonomi Dan Kegiatan Ekonomi Angkatan Kerja Di Provinsi Bali. PIRAMIDA 6(2).

Hukom, Alexandra.

Hubungan Ketenagakerjaan Dan Perubahan Struktur Ekonomi terhadap Kesejahteraan Masyarakat. Jurnal
Ekonomi Kuantitatif Terapan, [S.1.], nov. 2015. ISSN 2303-0186. Available at: <https://ojs.unud.ac.id/index.php/ jekt/article/view/16437>.

Date accessed: 24 nov. 2018. doi: https:// doi.org/10.24843/JEKT.2014. v07.i02.p04.

Kadariah. 1987. Pengantar Evaluasi Proyek. Lembaga Penelitian Fakultas Ekonomi Universitas Indonesia, Jakarta.

Margareni, Ni Putu Ayu Purnama., I Ketut Djayastra., dan I.G.W Murjana Yasa. 2016. Faktor-Faktor Yang Mempengaruhi Kemiskinan Di Provinsi Bali. PIRAMIDA Vol. XII No. $1: 101-110$.

Masyhuri dan Buhana. 2006. Analisis Komoditas Unggulan Sektor Pertanian di Kabupaten Brebes. Jurnal. Program Studi Magister Manajemen Agribisnis Sekolah Pascasarjana Universitas Gajah Mada.

Miranti, R., Duncan, A., \& Cassells, R. (2014). Revisiting the Impact of Consumption Growth and Inequality on Poverty in Indonesia during Decentralisation. Bulletin of Indonesian Economic Studies, vol 50 no 3 , 461- 482 .

Peneder, Michael. 2003. Industrial Structure and Aggregate Growth. Structural Change and Economic Dynamics, 14: h:427-448.

Priyasmini, Ni Made dan Dewa Nyoman Budiana. 2016. Analisis Perubahan Struktur Ekonomi dan Tenaga Kerja di Kabupaten Badung. E-Jurnal EP Unud. 5(11): h: 1168-1346.

Rice, Philip F dan Marshall J. Horton. 2010. Analysis of Recent Changes in Arkansas Personal Income: 20072009: A Shift-Share Approach. Journal 
of Business Administration Online, 9(2): h: 1-12

Richardson, Harry W. 1978. Dasar-Dasar Ekonomi Regional. Jakarta: Lembaga Penerbit FEUI.

Ridhwan, Masagus. 2013. Regional Dimensions of Monetary Policy in Indonesia. Bulletin of Indonesian Economic Studies, 49 (3), pp: 386-387.

Saerofi Mujib. 2005. Analisis Pertumbuhan Ekonomi dan Sektor Potensial di Kabupaten Semarang (Pendekatan Model Basis Ekonomidan SWOT). Jurnal Ilmiah. Sarjana Fakultas Ilmu Sosial Universitas Negeri Sebelas Maret Semarang.

Schaffer A. William. 2010. Regional Models of Income Determination: Simple Economic Base-Theory. Journal of Techiques for Analysis, pp:1-40.

Seran, Sirilius. Hubungan Antara Pendidikan, Pengangguran, dan Pertumbuhan Ekonomi dengan Kemiskinan. Jurnal Ekonomi Kuantitatif Terapan, [S.1.], may 2017. ISSN 2303-0186. Available at: <https://ojs.unud.ac.id/index.php/ jekt/article/view/23023>. Date accessed: 24 nov. 2018. doi: https:// doi.org/1 0.24843/JEK T.2017. v10.i01.p07.

Setiawan, Sigitdan Rudi Handoko. 2006. Pertumbuahan Ekonomi: Suatu Estimasi dan Arah Pencapaian Pertumbuhan yang Merata dan Berkualitas. Desember 2005, Kajian Ekonomi dan Keuangan, Vol. 9, No. 04 hal 1.

Sinaga, Dearlina. 2015. Determination Analysis of Leading Economic Sector Against Forming Region GDP in Simalungun. International Journal of Innovative Reaserch in
Management, 4 (3), pp: 1-12.

Sitohang, Paul. 1990. Dasar-dasar ilmu ekonomi Regional. Jakarta. FE UI.

Sri Budhi, Made Kembar. Analisis Faktorfaktor Yang Berpengaruh Terhadap Pengentasan Kemiskinan Di Bali: Analisis FEM Data Panel. Jurnal Ekonomi Kuantitatif Terapan, [S.1.], feb.2013.ISSN2303-0186.Availableat: $<$ https://ojs.unud.ac.id/index.php/ jekt/article/view/4506 $>$. Dateaccessed: 24 nov. 2018.

Suahasil, Nazara dan Hewings, Geoffrey. 2003. Towards Regional Growth Decomposition With Neigbor's Effect: a New Persfective on Shift-Share Analysis. Journal REAL 3 (21), pp: 1-18.

Suharyadi, Asep, Gracia Hadiwidjaja, and Sudarmo Sumarto. 2012. Economic Growth and Poverty Reduction In Indonesia Before and After the Asian Financial Crisis. Bulletin Of Indonesian Economic Studies, 48 (2), pp: 209-226.

Sugiyono. 2013. Metodelogi Penelitian Kuantitatif, Kualitatif dan R\&D. Bandung: Alfabeta.

Tambunan, Tulus. 2001. Perekonomian Indonesia: Teori dan Temuan Empiris. Jakarta : Ghalia Indonesia

Thomas R. Harris, George E. Ebai\& J. Scott Shonkwiler. 1998. A Multidimensional Estimation of Export Base. JRAP, 28 (1), pp:3-17.

Wiwekananda, Ida Bagus Putu; Suyana Utama, I Made. Transformasi Struktur Ekonomi dan Sektor Unggulan di Kabupaten Buleleng Periode 20082013. Jurnal Ekonomi Kuantitatif Terapan, [S.1.], july 2016. ISSN 2303- 
0186. Available at: <https://ojs.unud. ac.id/index.php/jekt/article/view/ 22746>. Date accessed: 24 nov. 2018. doi: https://doi.org/10.24843/ JEKT.2016.v09.i01.p04.

Woods, Jeffrey G. 2007. Regional Economic Growth And Income Ditribution In California. Journal Of Business And Public Affairs Vol.11.No1.pp: 34- 57.
Zheng Tian. 2013. Measuring Agglomeration Using The Standardized Location Quotient with a Bootstrap Method. The Journal of Regional Analysis \& Policy, 43 (2), pp:186-197. 